\title{
Environmental tools in product development
}

\section{Wenzel, Henrik; Hauschild, Michael Zwicky; Jørgensen, Jørgen; Alting, Leo}

\section{Published in:}

Proceedings of IEEE International Symposium on Electronics and the Environment

Link to article, DOI:

10.1109/ISEE.1994.337295

Publication date:

1994

\section{Document Version}

Publisher's PDF, also known as Version of record

Link back to DTU Orbit

\section{Citation (APA):}

Wenzel, H., Hauschild, M. Z., Jørgensen, J., \& Alting, L. (1994). Environmental tools in product development. In Proceedings of IEEE International Symposium on Electronics and the Environment (pp. 100-105). IEEE. https://doi.org/10.1109/ISEE.1994.337295

\section{General rights}

Copyright and moral rights for the publications made accessible in the public portal are retained by the authors and/or other copyright owners and it is a condition of accessing publications that users recognise and abide by the legal requirements associated with these rights.

- Users may download and print one copy of any publication from the public portal for the purpose of private study or research.

- You may not further distribute the material or use it for any profit-making activity or commercial gain

- You may freely distribute the URL identifying the publication in the public portal 


\title{
Environmental Tools in Product Development
}

\author{
Henrik Wenzel, Michael Z. Hauschild, Jørgen Jørgensen and Leo Alting \\ The Life Cycle Centre, Institute for Product Development \\ Building 403, The Technical University of Denmark \\ DK-2800 Lyngby, Denmark.
}

\begin{abstract}
A precondition for design of environmentally friendly products is that the design team has access to methods and tools supporting the introduction of environmental criteria in product development. A large Danish program EDIP" is carried out by the Institute for Product Development, Technical University of Denmark in cooperation with 5 major Danish companies aiming at development and test of such tools. These tools are presented in this paper.
\end{abstract}

\section{INTRODUCTION.}

Typically, product development work starts with a set of specifications, based on the assessment of market needs and company policies. The technical solutions are subsequently based on criterias such as manufacturing properties, cost, quality, etc. Environmental issues are normally given only minor attention during this process.

During the last decades environmental concern has been related to production processes, and environmental regulation has focused on pollution from production sites. In the industrialized world, however, there is a growing awareness, that this approach to environmental administration may not be sufficient.

The steadily increasing consumption of industrial products has led to increase in resource consumption, and environmental problems from other stages of the product life cycle. Thus, it is becoming generally regonized that the use and disposal phases as well as the raw material phase of the product life cycle are increasingly important and beyond sufficient control so far.

Recently environmental regulation and consumer pressure has begun to force manufacturers to become responsible for environmentally-safe disposal and recycling of used products.

*) Environmental Design of Industrial Products. The Programme is sponsored by the Danish Environmental Protection Agency. Partners include The Life Cycle Centre at the Institute for Product Development (prime contractor) and the industrial companies Bang \& Olufsen Ldt., Danfoss Ltd., Gram Ltd., Grundfos Ldt., and KEW Industries Ltd.
But even though recycling rates are increasing, huge amounts of solid waste are still deposited in landfills, creating serious pollution problems, and being an unacceptable waste of valuable resources. Extended responsponsibility for disposal and recycling is a step in the right direction. However, a concern for disposal cannot stand alone, and a more holistic approach is essential in future product development.

\section{DESIGN OF PRODUCT LIFE CYCLES}

A new approach in product development is necessary to manage environmental responsibilities. This new approach is based on the Life Cycle Concept as e.g. described by Alting and Jørgensen [1], [2]. The product must be developed and designed for all the life cycle phases: raw material aquisition, material production, product manufacturing, usage, disposal/recycling and transportation as shown in Fig. 1. The future task in product development can be called:

\section{Life Cycle Design of Products}

or even more challenging

$$
\text { Design of Product Life Cycles. }
$$

The product designer is to a very wide extent predisposing the environmental-, resource- and occupational health properties of the product. Selection of product concepts, structure, materials, surfaces, processes etc. is heavily influencing the environmental performance of the product throughout all stages of the product life.

Information of the environmental fate and effect of the product outside the designers own company is, however, very seldom available to the designer. To provide this insight, therefore, and to support the designer in an effort to design the product for the best possible environmental performance, a set of environmental methods and tools is required. 


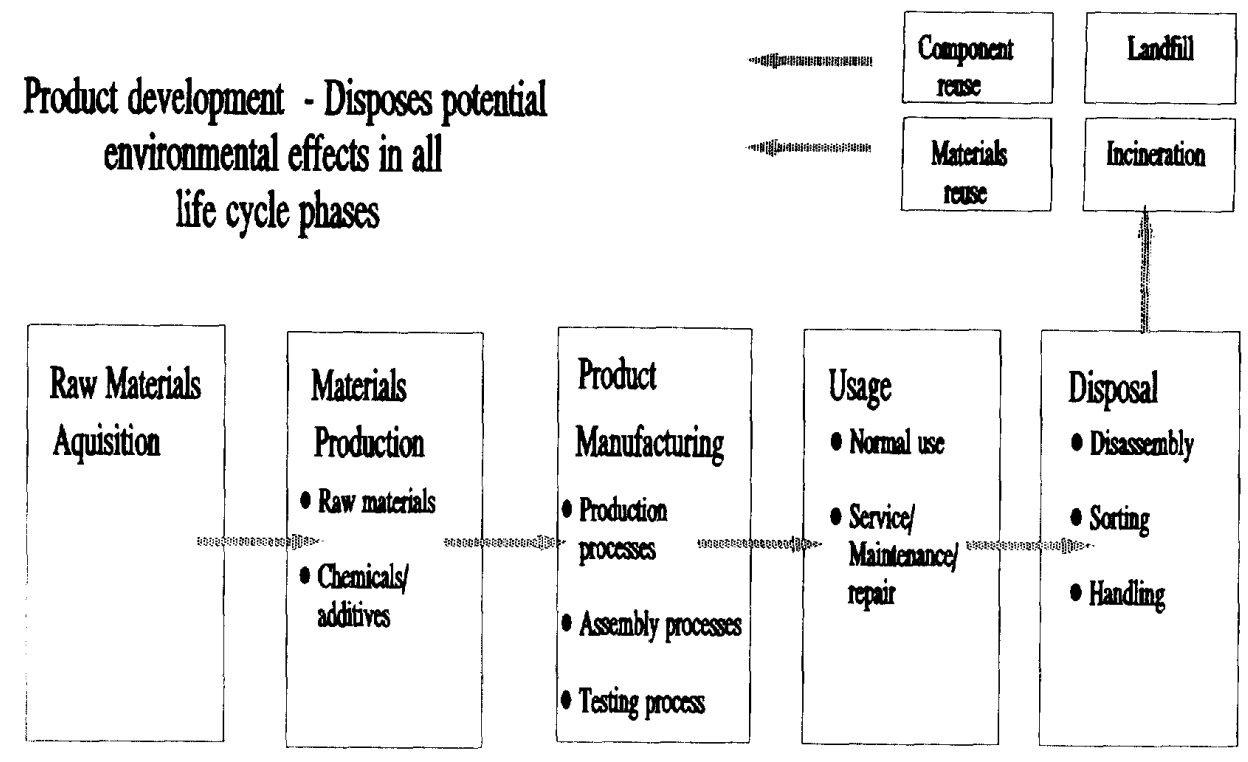

Fig. 1. The product life cycle.

At the Life Cycle Centre at the Institute for Product Development, Technical University of Denmark we have for some years been cooperating with industry in development of such tools. The basic strategy in developing these tools is that they must fit the needs of the product development function. The product development team must have access to a method or tool fit specifically to the types and levels of problem areas that evolves throughout the development process.

A systematic approach to product development has been structured by Olesen et al.[3]. This builds on the hypothesis that activities in product development can be structured in five main categories: 1) synthesize product, 2) model life cycle, 3) identify focus, 4) specify goals, and 5) verify results. These categories exist to a wider or less extent at all stages of the development porcess, and each of these main types of activities requires its own support. The above category 2 of course applies to development within a life cycle concept only.
Fig. 2 shows the key methods and tools in a general product development matrix in which these main product development activities and the typical development phases are shown. The matrix does not indicate a strictly stepwise procedure, but illustrates a principle of iterative development.

The listed tools do not cover the complete set according to all relevant environmental considerations and needs during the product development process. However, they represent some of the most important. The basic tool is the LCA-tool, consisting of three sub-tools: Life Cycle Modelling, Life Cycle Inventory and Life Cycle Assessment. These tools have been designed for the use in product development. They have reached a near-finished state, and have been tested in industry. They are described in detail by Wenzel and Hauschild in [4]. The other tools have been conceptually defined, and are under development. They are expected to be tested later this year. 


\begin{tabular}{|c|c|c|c|c|c|c|c|}
\hline Activities & \begin{tabular}{|l|} 
Idea \\
Phase
\end{tabular} & \begin{tabular}{|l|} 
Analysis \\
Phase
\end{tabular} & \begin{tabular}{|l} 
Goal \\
Definition \\
Phase \\
\end{tabular} & $\begin{array}{l}\text { Development } \\
\text { Phase }\end{array}$ & $\begin{array}{l}\text { Detail } \\
\text { Design } \\
\text { Phase }\end{array}$ & \begin{tabular}{|l|} 
Establishment \\
Phase
\end{tabular} & $\begin{array}{l}\text { Production } \\
\text { Phase }\end{array}$ \\
\hline $\begin{array}{l}\text { Synthesize } \\
\text { Product }\end{array}$ & \begin{tabular}{|l|} 
\\
Environmenta2 \\
Policies \\
Ideas \\
Market aspect \\
\end{tabular} & & 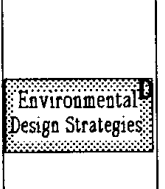 & $\begin{array}{l}\text { Exvironmental } \\
\text { Life Cycle In or }\end{array}$ & $\begin{array}{l}\text { Design Rules } \\
\text { vrmation }\end{array}$ & & \\
\hline $\begin{array}{l}\text { Model } \\
\text { Life Cycle }\end{array}$ & & 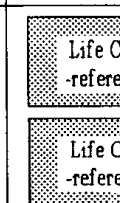 & $\begin{array}{l}\text { Modelling } \\
\text { products } \\
\frac{1}{\text { Ioventory }} \\
\text { products }\end{array}$ & 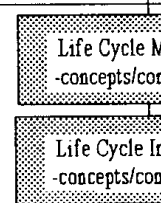 & 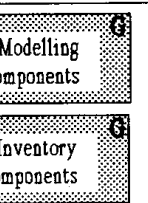 & & \\
\hline $\begin{array}{l}\text { Identify } \\
\text { Focos }\end{array}$ & & 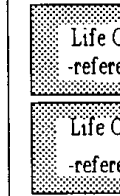 & $\begin{array}{l}\text { Assessment } \\
\text { products } \\
\begin{array}{l}\text { Dhagoosis: } \\
\text { products }\end{array}\end{array}$ & $\begin{array}{l}\text { Life Cycle } \mathrm{A} \\
\text { concepts con }\end{array}$ & 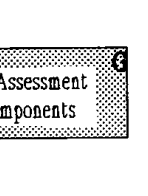 & & \\
\hline $\begin{array}{l}\text { Specify } \\
\text { Goals }\end{array}$ & & & $\begin{array}{l}\text { Evarironnentata } \\
\text { Specification }\end{array}$ & & & & \\
\hline $\begin{array}{l}\text { Verify } \\
\text { Results }\end{array}$ & & & & (3) Life Cycle 19 & le Modelling, -inv & ntory and -assessm & eat \\
\hline
\end{tabular}

Fig 2. A simplified matrix for the use of environmental tools in product development based on a more detailed description in Olesen et al. [3].

III. ENVIRONMENTAL TOOLS

\section{A. Environmental policies}

A precondition in the use of environmental tools in product development is that the company has a clear environmental policy in general, and especially for the product development function. This overall company guideline gives an outline of the necessary framework for introducing environmental criteria in product development. The link between company policy and specifications in product development is discussed.

\section{B 1. Life Cycle Modelling}

This tool focuses on modelling the life cycle of a specific product [4]. The tool provides a framework for describing materials, production processes, usage, disposal/recycling, and energy- and transportation systems. One or more reference product are chosen as models to represent the life cycle of the product under development. A guideline for system definition and scoping is included in this tool. An example of the output from the Life Cycle Modelling tool is shown in Fig. 3. 


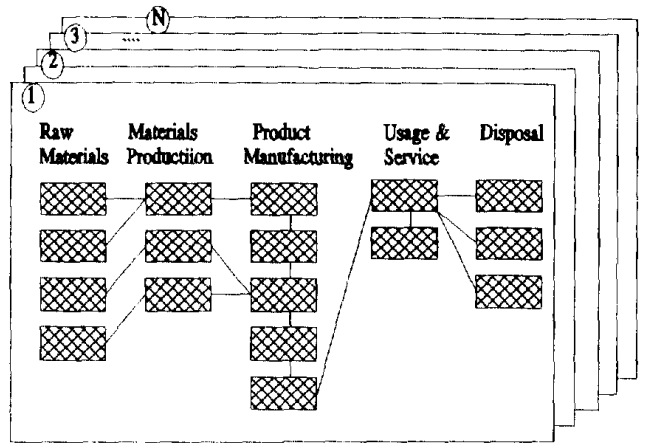

Fig. 3. Output from the Life Cycle Modelling tool: A model of the life cycle per component.

\section{B 2. Life Cycle Inventory}

The life cycle inventory tool provides a guideline for data collection and for partitioning of inputs and outputs from a proces in case in of recycling or co-production of two or more products [4]. Data concern energy consumption, material consumption, emissions and occupational health. The data are brought to uniform units so that they can be added into total numbers for alle components and life cycle processes. It is often difficult to achieve data and much work goes into this activity. In some cases the suppliers of materials do not have data and do not even know composition of the material on a substance specific level. Large suppliers, however, are much aware of the interest in data for LCA, and it seems that a breakthrough is on the way. Data for production processes can be difficult to achieve too, and it may be necessary to carry out own measurements.

As background for the tool a database including a number of general unit processes for each life cycle phase have been established. This can be used to fill in data for the life cycle of the product to give the first overview and set priorities for supplementary data collection.

An example of the output from the Lice Cycle Inventory tool is shown in Fig. 4.

\section{B 3. Life Cycle Assessment.}

The assessment tool provides a key to translate inventory data into potential environmental effects, resource consumptions $[4]$, and occupational health effects. Thus, this

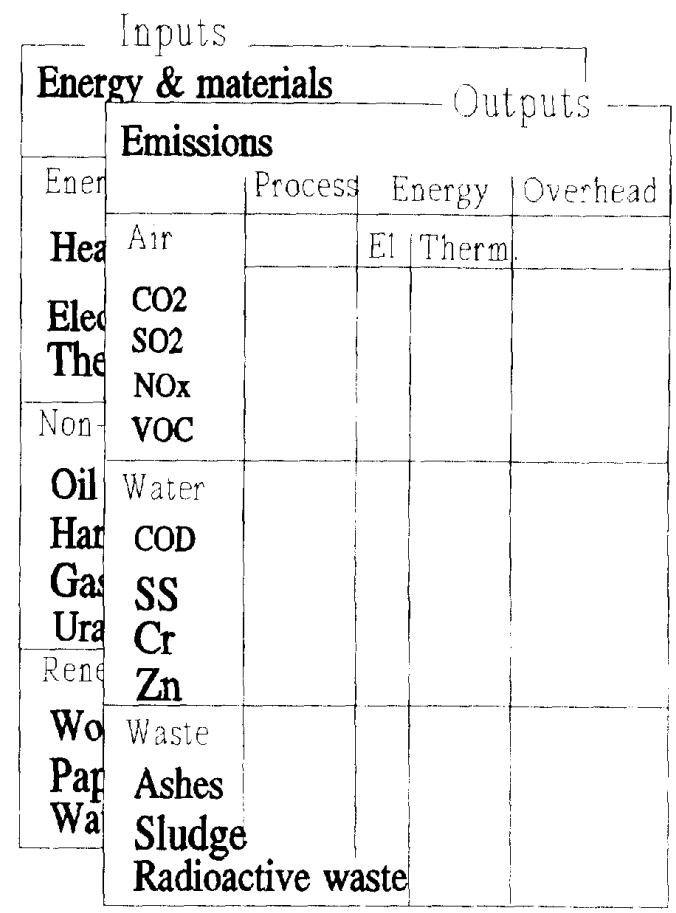

Fig. 4. Output from the Life Cycle Inventory tool: Tables of inputs and outputs from each of the included process in the product life cycle.

tool is essential as an aid to relate to the environmental significance of data. The tool also provides a set of reference emissions, resource consumption and ocupational health impacts i.e. reference contributions to each effect type on a global or national basis. This facility allows data for the product to be related to a known reference, thus being normalized. This is essential in order to relate to the magnitude of the potential contribution to the various effect types compared to one another. The Life Cycle Modelling-, Inventory-, and Assessment tools generally follow the guidelines recommended by SETAC [5] [6], and elaborates further on these in order to fill in details, where SETAC-recommendations only cover the framework.

An example of the output from the Life Cycle Assessment tool is given in Fig. 5. 


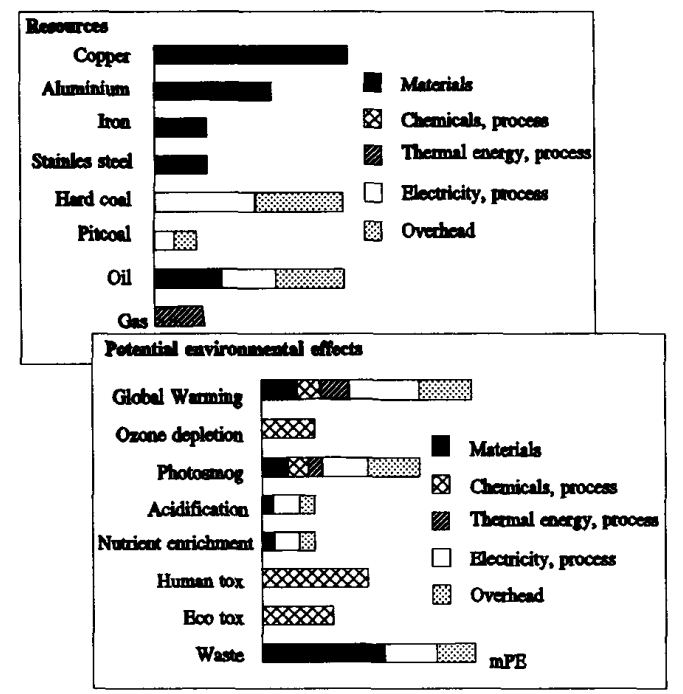

Fig. 5. An example of output from the Life Cycle Assessment tool. The figure shows normalized data expressed in milli-personequivalents (mPE).

\section{Life Cycle Diagnosis \\ - Environmental Improvement Potentials}

The diagnostic tool provides a guideline for analyzing environmental improvement potentials throughout the life cycle of the product [7]. On the basis of a theoretical study of the product functions theoretical improvement potentials are assessed. Subsequently practically achievable improvement potentials are assessed on the basis of reference products and technical experience. The tool includes a guideline for the procedure in this analysis of the practically achievable improvements. This involves an analysis of effect relationsships revealing the back-ground information necessary to understand how the improvement potentials can be implemented.

The result of this tool will be a prioritized list of focusing areas in the development of the new product. It is important that the efforts are concentrated on the significant contributors, for which improvement potentials are the largest. The fact that the diagnosis regards the improvement potentials proves a very important point being a basis for the whole set of tools: namely that the environmental illness of the product is not the absolute impacts but the non-realized improvement potentials.

An example of the output from the Life Cycle Diagnosis tool in given in Fig. 6.
Improvement potential in material recycling

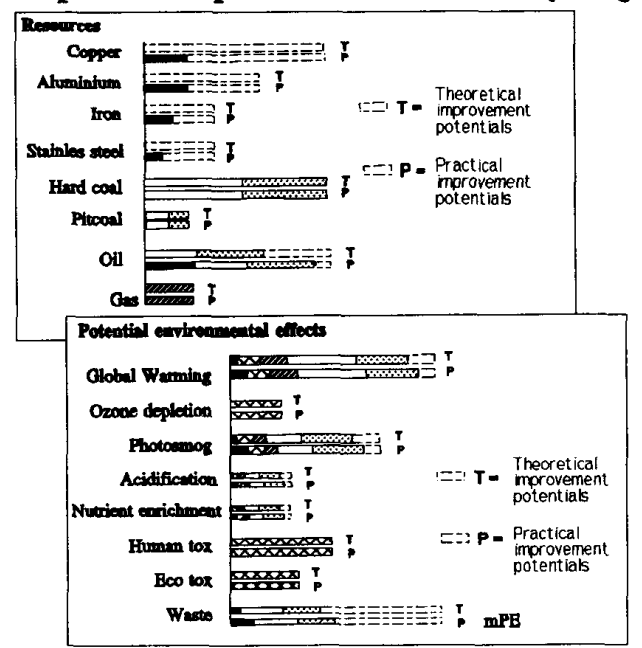

Fig. 6. An example of output from the Life Cycle Diagnosis tool. The figure shows an assessment of the improvement potential connected to material recycling.

\section{Environmental Design Strategies.}

This tool will provide a guideline for assessing the environmental benefit of overall design strategies based on the results from the life cycle assessment and the diagnosis.

\section{E. Environmental specifications.}

A paradigma is developed for establishing the environmental goals for the specific new product. Quantitative and qualitative goals are determined based on the life cycle assessment and the diagnosis following the prefered design strategies.

\section{F. Environmental and Design Rules}

This tool will build on a detailed knowledge of the causeeffect relations ships for the environmental performance of products and materials through all steps of the life cycle.

During diagnostic activities on a variety of products a basal knowledge of how to achieve improvements has been revealed. Answer to questions like: 
Why is $70 \%$ of a certain product deposited on landfill? Why not burned, or why not disassembled for material recovery?

Which product-specific reasons exist, and which societal reasons exist?

must be known to a degree that allows for meaningfull and effectfull design rules to be formed. The tool will contain principles, rules, checklists, and examples.

\section{G. Life Cycle Modelling, Inventory and Assessment of concepts/components.}

These tools are ment for modelling and assessing new products under development. They are essentially only simplified versions of the former described tools for reference products. They allow for a rough modelling of the life cycle based on product concepts and for comparison of alternative solutions to components and parts of the product.

\section{H. Life Cycle Assessment - New Products}

When a new product has been designed and production phases have been fully outlined, a complete LCA can be performed and used for documentation and as an update on the overall environmental company policy and strategy. The tools for this are the ones already described (B).

\section{FURTHER DEVELOPMENTS}

At the Life Cycle Centre, Institute for Product Development we have focused our work on

-Developing methods and tools to support the product development function to produce environmentally friendly products.

- Developing recycling strategies and technologies for various materials and products including electronic products [10].

- Developing cleaner manufacturing principles and processes.

Within each of these areas we have a number of specific projects running. A specific action is devoted to disposal of electronic products printed circuits boards, but it is too early to present specific results.

\section{CONCLUSION}

This paper presents a complex of tools which can support inclusion of environmental criteria in product development. It is shown how the tools support the various main disciplines in product development and how the tools build on one another to fulfil a spectrum of needs. The presented tools are being and/or planned to be tested tested in industry, and promissing results have been achieved.

\section{REFERENCES}

[1] Alting L. Designing for a lifetime. Manufacturing Breakthrough. May/June 93.

[2] Alting L \& Jørgensen J. The Life Cycle Concept as basis for sustainable industrial production. The Annal of CIRP: Vol. 42/1/1993.

[3] Olesen J, Hein L, Jørgensen J \& Wenzel H. Structuring and operationalization of EDIP tools in product development context. (Restricted paper in Danish): Institute for Product Development 1993.

[4] Wenzel H \& Hauschild MZ. Environmental Analysis in Product Development. Internal Report (in Danish) 1993.

[5] SETAC. A Technical Framework for Life Cycle Assessment. Workshop report: Smugglers Notch, Vermont, USA, 1991.

[6] SETAC: Guidelines for Life Cycle Assessment: A 'Code of Practice'. Edition 1. The SETAC workshop, Sesimbra, Portugal, 31 March 3 April 1993.

[7] Wenzel H, Nielsen AM \& Nedermark R. Environmental Life Cycle Diagnosis of Products. The 4th Annual Meeting, SETAC-Europe, Brussels 11-14 April 1994.

[8] Hauschild M, Wenzel H, Damborg A \& Torslev J. Methods for screening and quantitative assessment of ecotoxicity in life cycle analysis of products.

SETAC/SECOTOX Workshop. The Danish Technical University, Lyngby, 7-8 January 1993.

[9] Wenzel H \& Hauschild MZ. Toxicity Assessment in LCA of Products SETAC First World Conference on Ecotoxicity. Lissboa, 1993.

[10] Legarth J, Alting L, Eriksen H \& Gregersen JCG Development of Guidelines for Electronic Appliances. IEEE Inter natioanl Symposium on Electronica and the Environment. 2-4 May 1994, USA. 